\title{
The light chain but not the heavy chain of botulinum A toxin inhibits exocytosis from permeabilized adrenal chromaffin cells
}

\author{
B. Stecher, U. Weller*, E. Habermann*, M. Gratzl and G. Ahnert-Hilger \\ Abteilung Anatomie und Zellbiologie der Universität Ulm, $7900 \mathrm{Ulm}$, and *Rudolf-Buchheim-Institut für Pharmakologie \\ der Justus-Liebig-Universität, 6300 Giessen, FRG
}

Received 28 July 1989

\begin{abstract}
The heavy and light chains of botulinum $A$ toxin were separated by anion exchange chromatography. Their intracellular actions were studied using bovine adrenal chromaffin cells permeabilized with streptolysin $O$. Purified light chain inhibited the $\mathrm{Ca}^{2+}$-stimulated $\left.{ }^{3} \mathrm{H}\right]$ noradrenaline release with a half-maximal effect at about $1.8 \mathrm{nM}$. The inhibition was incomplete. Heavy chain up to $28 \mathrm{nM}$ was neither effective by itself nor did it enhance the inhibitory effect of light chain. It is concluded that the light chain of botulinum A toxin contains the functional domain responsible for the inhibition of exocyto-
\end{abstract}

sis.

Botulinum A toxin; Chain, light; Chain, heavy; Chromaffin cell, permeabilized; Exocytosis

\section{INTRODUCTION}

Botulinum A toxin (Botx A) belongs to the extremely poisonous clostridial neurotoxins $[1,2]$. The $150 \mathrm{kDa}$ protein consists of a heavy chain $(100 \mathrm{kDa})$ and a light chain $(50 \mathrm{kDa})$ covalently linked by a disulfide bond. It inhibits transmitter release from neurons $[1,2]$ as well as catecholamine release from adrenal chromaffin cells $[3,4]$. Direct application into the cytosol of adrenal chromaffin cells either by injection [5] or through large pores in the plasma membrane [6] confirmed that Botx A attacks a step during exocytosis common to neurons and chromaffin cells.

The inhibition of catecholamine release by both tetanus toxin and Botx $A$ is increased in the presence of a reducing agent $[6,7]$. This observation indicates that the disulfide bond linking the two chains in the clostridial neurotoxins has to be cleaved during their activation. Indeed the action of tetanus toxin is due to its light chain whereas its

Correspondence address: G. Ahnert-Hilger, Abt. Anatomie und Zellbiologie, Universität Ulm, Postfach 4066, $7900 \mathrm{UIm}$, FRG heavy chain has no effect [8]. In the present study we prepared and used the heavy and light chains of Botx A to find out which part of the molecule affects exocytosis and whether Botx $A$ is activated in the cell by a mechanism similar to that proposed for tetanus toxin [8].

\section{MATERIALS AND METHODS}

\subsection{Materials}

Botx A (two chain form) as obtained from Batelle Institute Frankfurt, FRG, was homogeneous in SDS gel electrophoresis. It was separated into its heavy and light chain by HPLC anion exchange chromatography using a modification of an LPLC procedure as described earlier [9]. All steps were performed at $18^{\circ} \mathrm{C}$ at pH 8.4 (adjusted with $\left.\mathrm{NaOH}\right)$. Typically $600 \mu \mathrm{g}(1 \mathrm{ml})$ Botx A were first desalted on an Econo-Pac 10GD (Bio-Rad) column and then applied to a Mono Q 5/5 (Pharmacia-LKB) column both equilibrated with buffer $A$ containing (mM): $\mathrm{Na}_{2} \mathrm{~B}_{4} \mathrm{O}_{7} 7.5$ and $\mathrm{NaH}_{2} \mathrm{PO}_{4} 15$. The Mono $\mathrm{Q}$ column was washed with $6 \mathrm{ml}$ of buffer A. For chain separation $50 \mathrm{mM}$ dithiothreitol (DTT) dissolved in $1.5 \mathrm{ml}$ of buffer $A$ was applied to the column and the flow stopped for $2 \mathrm{~h}$. Then the light chain was eluted at a rate of $0.25 \mathrm{ml} / \mathrm{min}$ with $7.5 \mathrm{ml}$ of a mixture of 9 parts buffer B (buffer A supplemented with $2 M$ urea and $50 \mathrm{mM}$ DTT) and one part of buffer $C$ containing (mM): $\mathrm{Na}_{2} \mathrm{~B}_{4} \mathrm{O}_{7} 75, \mathrm{NaH}_{2} \mathrm{PO}_{4} 150$, urea 2000, DTT 50. The absorbed heavy chain was finally eluted from the column with $7.5 \mathrm{ml}$ of 
buffer $\mathrm{C}$. Fractions were collected and the chains were localized using a protein assay [10]. Immediately after separation the chains were dialyzed against $\mathrm{KG}$ buffer I containing (mM): $\mathrm{K}^{+}$ glutamate 150 , Pipes 10, EGTA 0.5 , NTA 5, pH 7.2 supplemented with 1 or $5 \mathrm{mM}$ DTT. Toxicity (LD $\mathrm{L}_{50}$, s.c. in mice) was $1 \mathrm{ng} / \mathrm{kg}$ for the two chain form and between 1 and $5 \mu \mathrm{g} / \mathrm{kg}$ for the separated heavy or light chains, respectively. Botulinum A antitoxin, an immune serum from horse containing $750 \mathrm{IU} / \mathrm{ml}$ was obtained from Behring Werke Marburg, FRG; and dialyzed against KG-buffer I before use. Streptolysin $O$ (SLO) was purified [11]; it was kindly provided by S. Bhakdi (Giessen). The activity of SLO, routinely checked using $2.5 \%$ rabbit erythrocytes, is given in hemolytic units $(\mathrm{HU} / \mathrm{ml})$ [12].
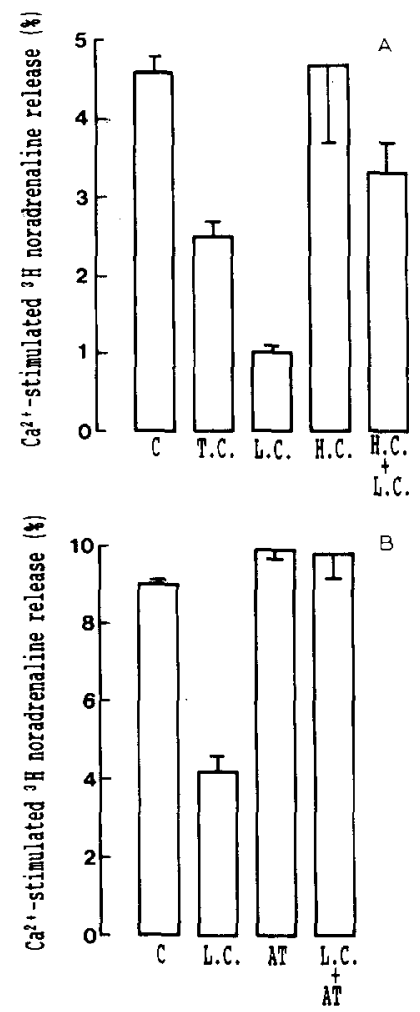

Fig.1. Specificity of the inhibitory effect of Botx A light chain on $\mathrm{Ca}^{2+}$ stimulated $\left[{ }^{3} \mathrm{H}\right]$ noradrenaline release from permeabilized chromaffin cells. (A) Permeabilized adrenal chromaffin cells were incubated with KG-buffer (see section 2), $5 \mathrm{nM}$ Botx A two chain form (T.C.), $5 \mathrm{nM}$ Botx A light chain (L.C.), $5 \mathrm{nM}$ Botx A heavy chain (H.C.) or a combination of $5 \mathrm{nM}$ heavy plus $5 \mathrm{nM}$ light chain for $25 \mathrm{~min}$ at $37^{\circ} \mathrm{C}$. Then they were stimulated for $10 \mathrm{~min}$ with fresh KG-buffer containing $30 \mu \mathrm{M}$ free $\mathrm{Ca}^{2+}$. Release in the absence of $\mathrm{Ca}^{2+}$ $(3.9 \pm 0.2)$ was subtracted. (B) Prior to the addition of $\mathrm{Ca}^{2+}$ (30 $\mu \mathrm{M}$ free) the permeabilized cells were incubated for $25 \mathrm{~min}$ at $37^{\circ} \mathrm{C}$ with $\mathrm{KG}$-buffer, $5 \mathrm{nM}$ light chain, or $7.5 \mathrm{IU} / \mathrm{ml}$ botulinum A antitoxin (AT) or $5 \mathrm{nM}$ light chain plus $7.5 \mathrm{IU} / \mathrm{ml}$ AT. All additives were kept for $2 \mathrm{~h}$ at room temperature before use. Release in the absence of $\mathrm{Ca}^{2+}(3.6 \pm 0.3)$ was subtracted. Values are the mean of 3 samples \pm SD.

\subsection{Methods}

Chromaffin cells from bovine adrenal medulla were prepared and kept in short-time cultures as described ([6], for review see [13]). After preloading the cells with tritiated noradrenaline they were permeabilized with SLO $(60 \mathrm{HU} / \mathrm{ml})$ for $2 \mathrm{~min}$ at $37^{\circ} \mathrm{C} \mathrm{[12]} \mathrm{and} \mathrm{incubated} \mathrm{between} 5$ and $25 \mathrm{~min}$ with the respective toxin preparation dissolved in KG buffer II (KG-buffer I containing additional $2 \mathrm{mM} \mathrm{Mg}{ }^{2+} /$ ATP complex and $1 \mathrm{mM}$ free $\mathrm{Mg}^{2+}$ ) supplemented with $0.1 \%$ BSA and $1 \mathrm{mM}$ DTT. Finally the cells were stimulated with fresh KG buffer II containing micromolar amounts of free $\mathrm{Ca}^{2+}$ for $10 \mathrm{~min}[6,12]$. Free $\mathrm{Ca}^{2+}$ concentrations were calculated using the stability constants given [14] and were routinely monitored by a $\mathrm{Ca}^{2+}$-sensitive electrode [15].

\section{RESULTS}

$\mathrm{Ca}^{2+}$-induced catecholamine release from SLOpermeabilized adrenal medullary chromaffin cells in primary culture is affected by the two chain form of Botx A (5 nM) in the presence of $1 \mathrm{mM}$ DTT (fig.1A and [6]). When given alone the light chain ( $5 \mathrm{nM}$ ) inhibited $\mathrm{Ca}^{2+}$ induced exocytosis from permeabilized adrenal chromaffin cells, whereas the same amount of heavy chain was ineffective (fig.1A). The equimolar mixture of the

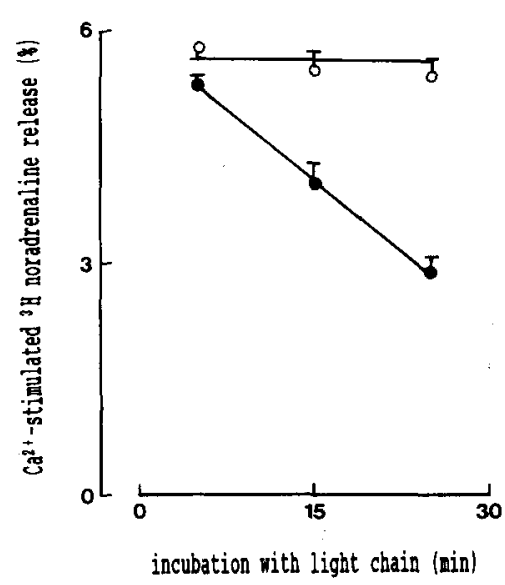

Fig.2. Time course of the inhibitory action of Botx A light chain on $\mathrm{Ca}^{2+}$-stimulated $\left[{ }^{3} \mathrm{H}\right]$ noradrenaline release. Permeabilized adrenal chromaffin cells were incubated for $25 \mathrm{~min}$ in $\mathrm{KG}$ buffer 11 (see section 2.2) supplemented with $0.1 \%$ BSA and $1 \mathrm{mM}$ DTT. Botx A light chain (5 nM) (closed symbols) was present either from the beginning or added $15 \mathrm{~min}$ or $5 \mathrm{~min}$ before the buffer was replaced by a fresh one containing either no or $30 \mu \mathrm{M}$ free $\mathrm{Ca}^{2+}$. Controls (with no light chain added, open symbols) were treated similarly. Values represent the $\mathrm{Ca}^{2+}$ stimulated release of 3 samples \pm SD. Release in the absence of $\mathrm{Ca}^{2+}(4.0 \pm 0.7$ for controls and $4.1 \pm 0.2$ for light chain present for $25 \mathrm{~min}$ ) was subtracted. Values are the mean of 3 samples $\pm \mathrm{SD}$. 
heavy and the light chain was rather less effective than the separated light chain alone (fig.1A, see also fig.3). The inhibitory action of the light chain was prevented by preincubation with antitoxin indicating its specific action. The antitoxin itself did not modify exocytosis from the permeabilized chromaffin cells (fig.1B).

The inhibitory action of the light chain increased with the incubation time as previously shown for the two chain toxin [6]. The light chain was present either for 5,15 , or $25 \mathrm{~min}$ prior to the stimulation with $\mathrm{Ca}^{2+}$. A slight inhibition of exocytosis was observed during $5 \mathrm{~min}$ presence of light chain, which increased to about $50 \%$ after $25 \mathrm{~min}$. Even when present during the whole incubation period the light chain did not alter the basal release (fig.2).

The inhibitory action of Botx A light chain was always incomplete. It started already below $1 \mathrm{nM}$, was maximal with doses over $5 \mathrm{nM}$ and half maximal at $1.8 \pm 1.2 \mathrm{nM}(\mathrm{SD} ; n=4)$. The presence of $28 \mathrm{nM}$ Botx A heavy chain did not add to the inhibitory action caused by the light chain. Indeed

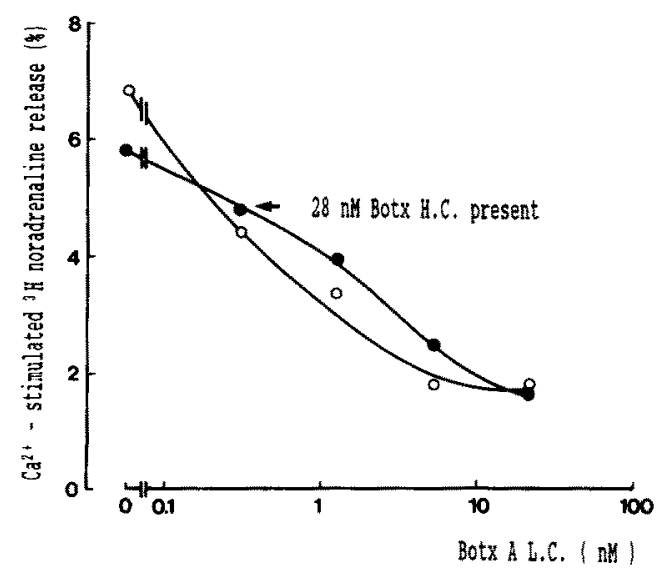

Fig.3. Dose-response curve of the inhibitory action of Botx A light chain on exocytosis in the absence or presence of its heavy chain. Permeabilized adrenal chromaffin cells were incubated for $25 \mathrm{~min}$ at $37^{\circ} \mathrm{C}$ in $\mathrm{KG}$ buffer II with increasing amounts of light chain (abscissa). The buffer was replaced with fresh buffer either with or without $30 \mu \mathrm{M}$ free $\mathrm{Ca}^{2+}$ and cells were further incubated for $10 \mathrm{~min}$. The values represent the $\mathrm{Ca}^{2+}$ stimulated release. The effects of Botx A light chain in the absence (open symbols) or presence (closed symbols) of $28 \mathrm{nM}$ Botx A heavy chain are shown. Controls were also run in the absence or presence of heavy chain. Values (mean of two samples) in the absence of $\mathrm{Ca}^{2+}(3.4 / 3.8$ for controls and 3.6/3.7 for $28 \mathrm{nM}$ heavy chain) were subtracted. Note that Botx A heavy chain did not substantially alter the $\mathrm{Ca}^{2+}$ stimulated release. rather a slight reduction of the efficacy of the light chain was observed (fig.3, see also fig.1A).

\section{DISCUSSION}

The results reported here indicate that the light chain of Botx A contains the functional domain responsible for the intracellular inhibition of exocytosis. Addition of heavy chain rather inhibits than promotes the inhibitory effect. As already shown for tetanus toxin in Aplysia neurons [16] and chromaffin cells [8], inhibition of exocytosis due to Botx A can be mimicked by its light chain. The fact that only part of their molecules is required to elicit the intracellular effects adds the clostridial neurotoxins to a group comprising cholera toxin [17], diphtheria toxin [18], pertussis toxin [19] and the botulinum toxin $C_{2}$ [20]. In these toxins a larger subunit mediates binding and promotes internalization whereas a smaller component is an enzyme which affects various intracellular processes. However, any enzymatic activity of the light chain of either Botx A or tetanus toxin is still to be found.

The action of the Botx $A$ light chain in chromaffin cells differs from that in Aplysia neurons. Here both the heavy and the light chain of Botx A must be present to inhibit transmitter release [21] whereas in chromaffin cells the action of Botx A light chain is independent of the heavy chain (this study). On the other hand the light chain of tetanus toxin alone is fully active in both Aplysia neurons [16] and adrenal chromaffin cells [8]. The differences may be caused by the chemical instability of the Botx A light chain. When given alone it might quickly lose its activity in the high osmolar medium required for the Aplysia neurons. Addition of the heavy chain may stabilize the light chain which then inhibits exocytosis.

The modes of action of tetanus toxin and botulinum $\mathrm{A}$ toxin are not strictly identical. This is true for the neuromuscular junction of the mouse hemidiaphragm [22] and for adrenal chromaffin cells $[6,8]$. Thus Botx A but not tetanus toxin may attack a step during exocytosis which is different in neurons as compared to chromaffin cells.

Further studies using endocrine cells and mammalian neurons will be necessary to shed light on the pharmacokinetics and pharmacodynamics of clostridial neurotoxins at the cellular level. 
Acknowledgements: We thank Drs S. Bhakdi (Giessen) for streptolysin $O$ and $W$. Simon (Zürich) for the membranes of the $\mathrm{Ca}^{2+}$-specific electrode. We are indebted to Margit Rudolf (Ulm), Sabine Jessen and Martina Hudel (Giessen) for expert technical assistance. This work was supported by the Deutsche Forschungsgemeinschaft (SFB 249, Gr 681), the Fonds der chemischen Industrie, and the state of Baden-Württemberg.

\section{REFERENCES}

[1] Habermann, E. and Dreyer, F. (1986) Curr. Top. Microbiol. Immunol. 129, 93-179.

[2] Simpson, L.L. (1989) Botulinum Neurotoxin and Tetanus Toxin (Simpson, L.L. ed.) Academic Press, San Diego, CA.

[3] Knight, D.E. (1986) FEBS Lett. 207, 222-226.

[4] Marxen, P., Fuhrmann, B. and Bigalke, H. (1989) Toxicon, in press.

[5] Penner, R., Neher, E. and Dreyer, F. (1986) Nature 324, 76-78.

[6] Stecher, B., Gratzl, M. and Ahnert-Hilger, G. (1989) FEBS Lett. 248, 23-27.

[7] Ahnert-Hilger, G., Bader, M.-F., Bhakdi, S. and Gratzl, M. (1989) J. Neurochem. 52, 1751-1758.

[8] Ahnert-Hilger, G., Weller, U., Dauzenroth, M.-E., Habermann, E. and Gratzl, M. (1989) FEBS Lett. 242, 245-248.
[9] Sathyamoorthy, V. and DasGupta, B.R. (1985) J. Biol. Chem. 260, 10461-10466.

[10] Bradford, M. (1976) Anal. Biochem. 72, 248.

[11] Bhakdi, S., Roth, M., Sziegoleit, A. and Tranum-Jensen, J. (1984) Infect. Immun. 47, 52-60.

[12] Ahnert-Hilger, G., Mach, W., Föhr, K.J. and Gratzl, M. (1989) Methods Cell Biol. 31, in press.

[13] Livett, B. (1984) Physiol. Rev. 64, 1103-1161.

[14] Sillen, L. and Martell, A. (1971) Chem. Soc. (Lond.) suppl.1.

[15] Ammann, D., Bührer, T., Schefer, U., Müller, M. and Simon, W. (1987) Pflügers Arch. 409, 223-228.

[16] Mochida, S., Poulain, B., Weller, U., Habermann, E. and Tauc, L. (1989) FEBS Lett., in press.

[17] Cassel, D. and Pfeuffer, T. (1978) Proc. Natl. Acad. Sci. USA 75, 2669-2673.

[18] Hudson, T., Scharff, J., Kimak, M. and Neville, D. (1988) J. Biol. Chem. 263, 4773-4781.

[20] Kaslow, H.R., Kim, L.-K., Moss, J. and Lesikar, D. (1987) Biochemistry 26, 123-127.

[21] Aktories, K., Bärmann, M., Ohishi, I., Tsuyama, S., Jakobs, K.-H. and Habermann, E. (1976) Nature 322, 390-392.

[22] Poulain, B., Tauc, L., Maisey, E.A., Wadsworth, J.D.F., Mohan, P.M. and Dolly, J.O. (1988) Proc. Natl. Acad. Sci. USA 85, 4090-4094.

[22] Dreyer, F., Becker, C., Bigalke, H., Funk, J., Rosenberg, F. and Ziegler, M. (1984) J. Physiol. 79, 252-258. 